\title{
Optimization of Extraction Parameters for Recovery of $\alpha$ - amylase from the Fermented Bran of Bacillus circulans GRS313
}

\author{
Soumen Palit and Rintu Banerjee* \\ Microbial Biotechnology and Down stream processing laboratory, Department of Agricultural and Food \\ Engineering; Indian Institute of Technology, Kharagpur-721302, West Bengal, India
}

\begin{abstract}
The extraction of $\boldsymbol{\alpha}$ amylase in the solid state fermentation of wheat bran by Bacillus circulans GRS313 was optimized. Among various solvents tested, maximum extraction was achieved when $2.5 \%(v / v)$ glycerol was added. The optimum conditions for extraction were 2.5 hrs soaking time at $30^{\circ} \mathrm{C}$ under recirculation and agitated condition, which yielded $590 \mathrm{U} / \mathrm{g}$ bran of enzyme activity. Whereas under stationary soaking condition the activity of the enzyme was $439.58 \mathrm{U} / \mathrm{g}$ bran. With repeated wash under the above optimum conditions showed that $600 \mathrm{U} / \mathrm{g}$ and $184.2 \mathrm{U} / \mathrm{g}$ of enzyme extracted in the 1st and 2 nd washes respectively and only $36.84 \mathrm{U} / \mathrm{g}$ was recovered in the $3 \mathrm{rd}$ wash
\end{abstract}

Key words: Bacillus circulans; Solid state fermentation; $\alpha$ - amylase: Extraction

\section{INTRODUCTION}

$\alpha$-Amylases are responsible for hydrolysis of $\alpha-1$, -4-glucosidic bonds in amylose, amylopectin and glycogen in endo-fashion. $\alpha$-Amylases are mostly employed in pharmaceutical, textile, baking, brewing, paper coating, starch and syrup industries. $\alpha$-Amylases are also used as digestive aid, detergents and for sewage treatment. There are reports of production of this enzyme from bacteria using solid state fermentation (Lonsane \&Ramesh, 1990; Ramesh \&Lonsane, 1988;Ramesh \&Lonsane, 1987). In solid state fermentation the products are formed at or near the surfaces of the solid materials with low moisture content (Selvakumar \& Pandey, 1999). So it is necessary to select a solvent for leaching out the product from the fermented mass. Depending upon its application on process economics and to reduce further downstream processing costs, various techniques have been developed by the researchers (Castillo et al 1985; Bjusrstorm, 1985; Caltron, Coobs \& Hmman, 1986).

To isolate the required product from the fermented biomass the report on solid state fermentation of $\alpha$-amylase production from Bacillus circulans is very much limited. The present communication deals with the efficiency of leaching of the enzyme amylase from the fermented biomass using the same strain.

\section{MATERIALS AND METHODS}

Microorganism The organism used was Bacillus circulans GRS313, a strain isolated from the soil

\footnotetext{
"Author for correspondence
} 
of IIT Kharagpur. It was routinely maintained at 4 ${ }^{0} \mathrm{C}$ on $1 \%$ (w/v) nutrient agar slants.

Method of fermentation: The fermentation was carried out in $250 \mathrm{ml}$ Erlenmeyer flasks containing $10 \mathrm{~g}$ of wheat bran, $0.05 \%(\mathrm{w} / \mathrm{w})$ urea, $.25 \%(\mathrm{w} / \mathrm{w})$ $\mathrm{MgCl}_{2}, .25 \%(\mathrm{w} / \mathrm{w}) \mathrm{KCl}$, ribose $1 \%(\mathrm{w} / \mathrm{w}), 25 \mathrm{ml}$ deionized water which was autoclaved for 20 mins at $121{ }^{\circ} \mathrm{C}$. A cell suspension of $1 \%$ (v/w bran) containing $3 \times 10^{9}$ viable cells $/ \mathrm{ml}$ was used as inoculum. Incubation was carried out for $60 \mathrm{hrs}$ at $40{ }^{\circ} \mathrm{C}$ and $95 \% \mathrm{RH}$.

Extraction process: Extraction was conducted using $10 \mathrm{~g}$ fermented mass in $250 \mathrm{ml}$ conical flask. Extraction was done by soaking the fermented solid with a suitable solvent for a desired period .The crude extract was then squeezed out through a cotton cloth. The clear extract obtained after centrifugation to remove insolubles, assayed for amylolytic activity. The parameters selected for this study were type of solvent, volume of solvent, soaking time, physical state of leaching, soaking temperature and number of washes. The optimized values were repeated thrice in order to corroborate their validity.

Enzyme assay: The enzyme activity was assayed following the method of Bernfeld (Bernfeld, 1955) using 3,5-dinitrosalicylic acid. The absorbance was measured at $540 \mathrm{~nm}$. One unit of enzyme activity was defined as the amount of enzyme that release $1 \mu$ mole of reducing sugar as glucose per minute under the assay condition specified.

\section{RESULTS AND DISCUSSION}

Solvent Selection:The extraction efficiency is critical to the recovery _of the enzyme from the fermented_biomass, hence selection of a suitable solvent is necessary. Different solvents selected for this study were water, .1M acetate buffer $\mathrm{pH}$ $4.5,10 \%(\mathrm{v} / \mathrm{v})$ aqueous mixture of glycerol, $10 \%$ $(\mathrm{v} / \mathrm{v})$ aqueous mixture of ethanol, $10 \%(\mathrm{v} / \mathrm{v})$ aqueous mixture of methanol, 10\%, (v/v) aqueous mixture of acetone, $10 \%(\mathrm{v} / \mathrm{v})$ glycerol prepared in $.1(\mathrm{M})$ acetate buffer of $\mathrm{pH} 4.5$. From fig (1) it is clear that among all the solvents used_10\% (v/v) aqueous mixture of glycerol gave the best result.

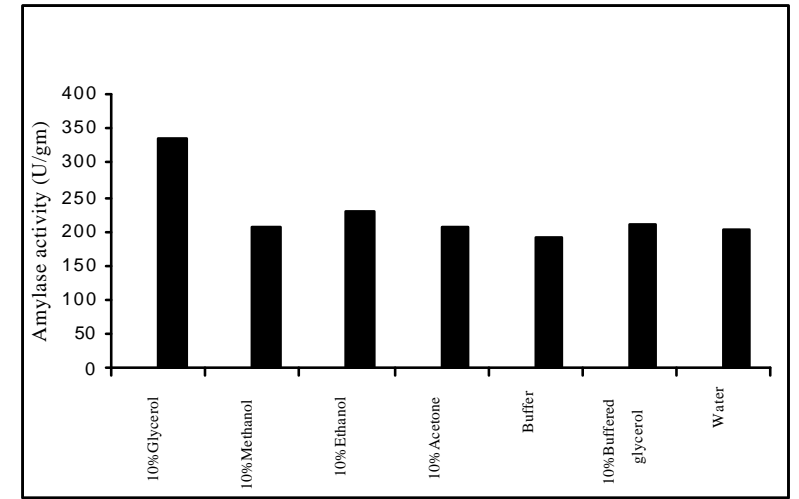

Figure 1 - Selection of solvent for Amylase extraction

Which indicate that organic solvents are more effective as soaking solvents than the inorganic ones, the reason can be explained by DebyeHickel theory (Maron \&Prutton eds 1965)

$$
\mathrm{F}=\mathrm{I} / \mathrm{D} /\left(\mathrm{Q}_{1} \mathrm{Q}_{2}\right) / \mathrm{r}^{2}
$$

Where $\mathrm{F}=$ force of attraction or repulsion, $\mathrm{D}$ =dielectric constant, $\mathrm{Q}_{1}, \mathrm{Q}_{2}=$ charges of the attracting molecules, $\mathrm{r}=$ distance of two attracting molecules. All solvents have its own dielectric constant, organic solvents posses lower dielectric constantthan inorganic solvents, so water possesses higher dielectric constant than organic solvents, therefore from the above theory it can be concluded that force of interaction between amylase and solvent may have increased due to lowered dielectric constant of the extracting solvent, glycerol. Though other organic solvent posses lower dielectric constant than glycerol they may have some inhibitory effect on enzyme activity

Glycerol Concentration: As 10\% (v/v) glycerol was found to be the best solvent among all, in the next set of experiment the concentration of glycerol was further varied from $0.5 \%(\mathrm{v} / \mathrm{v})$ to $10 \%(\mathrm{v} / \mathrm{v})$. It was found that $2.5 \%(\mathrm{v} / \mathrm{v})$ aqueous mixture of glycerol is capable of extracting maximum amount of enzyme from the fermented bran Fig (2). This may be because at a concentration of $2.5 \%(\mathrm{v} / \mathrm{v})$ the hydroxyl group of the glycerol forms hydrogen bond with the protein molecules, which gives better stability to the enzyme molecule (Stryer, 1975) and there might be some inhibitory effect due to distortion of enzyme structure at higher concentration of glycerol. It has been reported that the stability of the enzyme molecules can be improved by using solvent such as sorbitol (Bailey \&Ollis eds, 1986) 


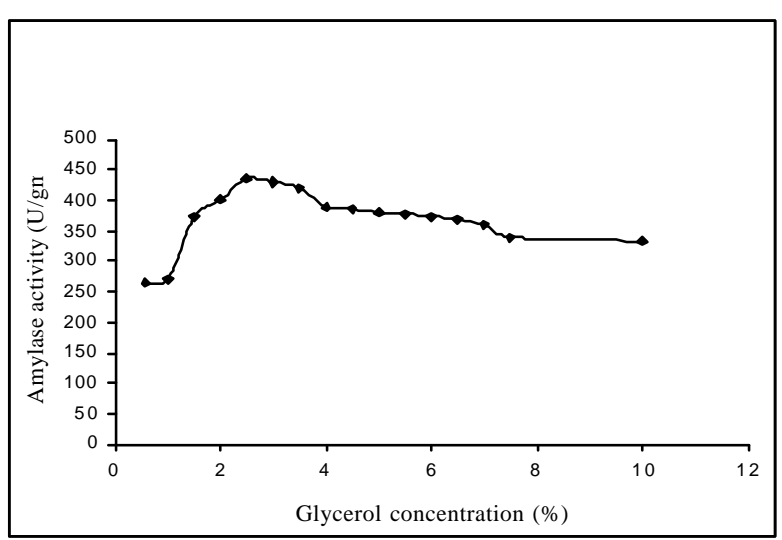

Figure 2 - Effect of glycerol concentration on Amylase extraction process

Solid to Solvent Ratio: In SSF system free flowing solvent is very much limited. Thus adequate amount of solvent is required to leach out the enzyme present.

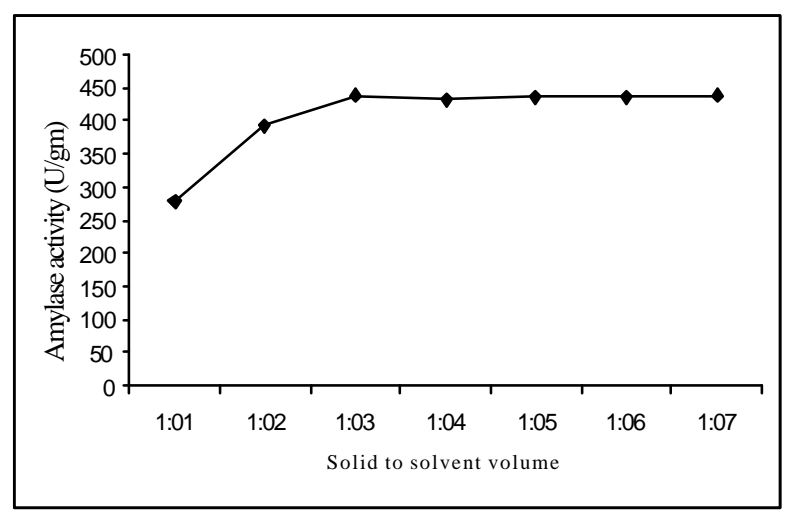

Figure 3 - Effect of solvent volume on amylase extraction.

The volume of the solvent i.e. 2.5\% glycerol mixture was varied from $10 \mathrm{ml}$ to $70 \mathrm{ml}$ and extraction was done after $3 \mathrm{hrs}$ of soaking. It was found that Fig (3) $30 \mathrm{ml}$ solvent in $10 \mathrm{~g}$ of fermented bran, i.e. solid to solvent ratio of 1:3 was optimum. It was observed that total activity remains constant even though the solvent volume was increased by many folds, but there was a decrease in total activity when lower volume of solvent was used for extraction. This might be due to insufficient solvent volume to penetrate the solid fermented mass.

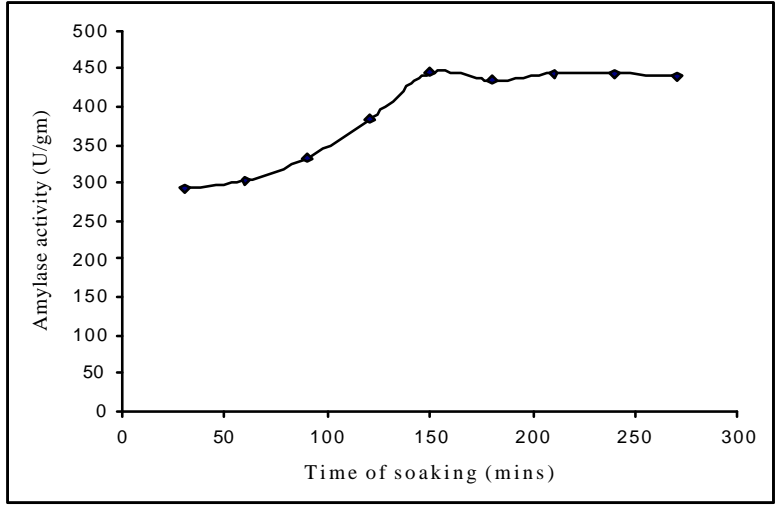

Figure 4 - Effect of incubation time on soaking.

Incubation time for soaking: Keeping the solvent concentration and its volume at optimum level, incubation time for soaking was optimized for maximum enzyme recovery from the fermented bran. The time period was varied from $30 \mathrm{~min}$ to $270 \mathrm{~min}$ as shown in Fig (4). It was found that $150 \mathrm{~min}$ soaking was optimum and beyond that it did not have any additional effect on amylase extraction indicating the minimum time for the total penetration of solvent through the fermented biomass.

Physical state of leaching: Three different leaching conditions were studied viz.stationary, agitation and recirculation. The results show that Fig (5) both agitation and recirculation conditions were effective for the leaching process.

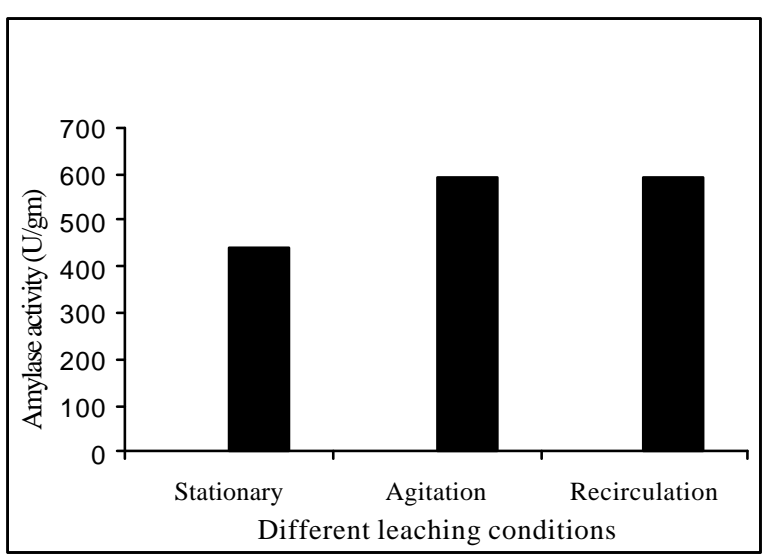

Figure 5 - Effect of different leaching conditions on amylase extraction.

This effect is quite justified because on agitation fermented bran gets distributed uniformly in the continuous phase of solvent, reducing concentration polarization (Tunga, Banerjee 
\&Bhattarcharya, 1999). During recirculation an additional drag force was added by the peristaltic pump, which facilitated the extraction process, by isolating maximum amount of amylolytic enzyme.

\section{Effect of temperature on leaching process:}

To study the effect of temperature on the leaching process the temperature was varied from $20{ }^{\circ} \mathrm{C}$ to $70{ }^{\circ} \mathrm{C}$ each at $10{ }^{\circ} \mathrm{C}$ intervals. It was observed that $30{ }^{0} \mathrm{C}$ was the most effective condition for leaching of the enzyme Fig (6), but at the higher temperature the yield was less. This might be due to the denaturation of the enzyme.

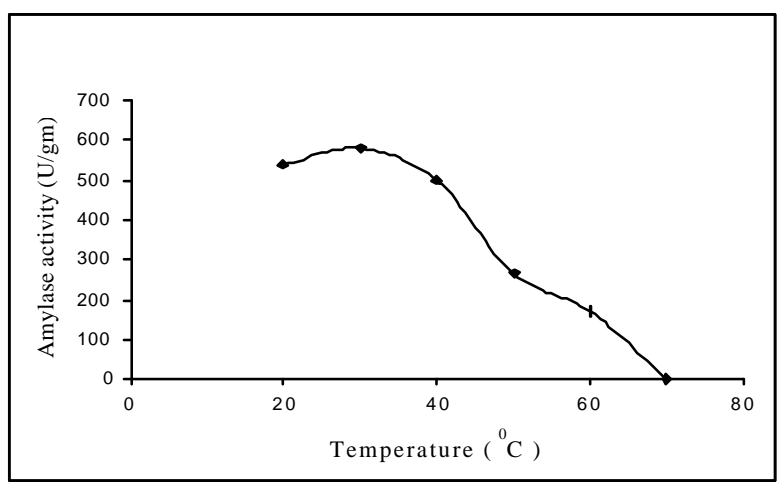

Figure 6 - Effect of temperature on leaching.

Number of wash: The above parameter was optimized by adding a fresh aqueous mixture of $2.5 \%$ glycerol after the extraction for each wash. It was observed that out of three washes the first two were sufficient for maximum leaching of the enzyme. As expected, the first wash was more effective Fig (7).

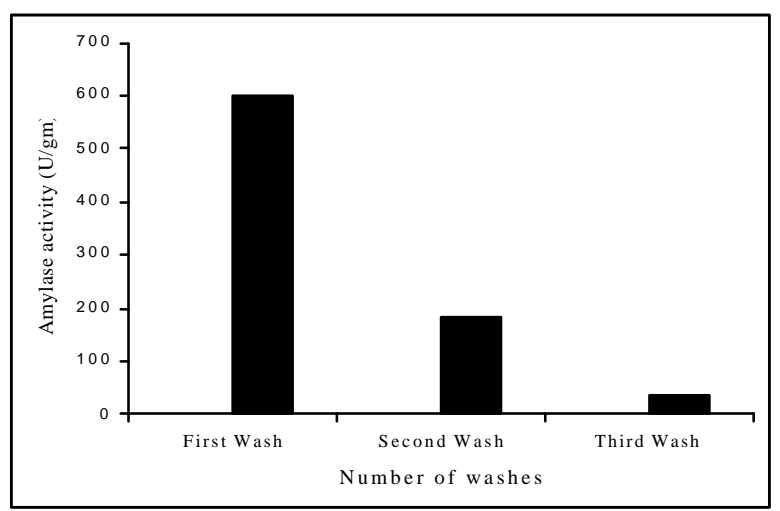

Figure 7 - Effect of number of washes on Amylase extraction

The subsequent washes did not have significant effect on extraction.

\section{RESUMO}

Otimizou-se a extração de $\alpha$ - amilase na fermentação no estado sólido do farelo de trigo Bacillus circulans GRS313 . Entre vários solventes testados, conseguiu-se a melhor extração com solução $2,5 \%$ (v/v) de glicerol. As condições ótimas de extração foram de 2,5 horas de tempo de contato a $30^{\circ} \mathrm{C}$ sob condições de agitação e recirculação, chegando a uma atividade enzimática de $590 \mathrm{U} / g$ farelo, enquanto chegou-se a uma atividade enzimática de $439.58 \mathrm{U} / \mathrm{g}$ farelo sob condições de contato estacionárias. Com lavagens repetidas nas condições ótimas descritas acima, chegou-se à uma atividade enzimática de $600 \mathrm{U} / \mathrm{g}$ farelo e 184,2 U/g de enzima extraída nas $1^{\text {a }}$ e 2 lavagens, respectivamente, e apenas 36,84 $\mathrm{U} / \mathrm{g}$ recuperada na $3{ }^{\mathrm{a}}$ lavagem.

\section{REFERENCES}

Bjusrstorm, EE. (1985), Biotechnology Fermentation and Down stream processing, Chem Engg, 92, 120158.

Bernfeld, P. (1955), Amylase $\alpha / \beta$, Methods Enzymol 1, 149

Baily, J.E,Ollis,D.E.(eds). (1986), Biochemical Engineering Fundamentals, McGraw Hill New York

Castillo, L.R, Alves, L.M Tito, Medronho, A. Ricardo. (1999), Recovery of Pectolytic enzymes producd by Solid State culture of Aspergillus niger, Process Biochemistry, 34, 181-186

Caltron, G.J, Coobs, C.S, Hmman, J.P. (1986), Manual of Industrial Microbiology and Biotechnology, American society of microbiology Washington. U.S.A, 436-445

Losane, B. K. \& Ramesh, M. V. (1990), Production of bacterial thermostable $\alpha$-amylase by SSF. A potential tool for achieveing economy in enzyme production and starch hydrolysis, Av. Appl. Microbiol, 35,1-56

Maron, S. H, Prutton C. F. (Eds). (1965), Principles of physical chemistry, Oxford and IBH publishing Co. Pvt. Ltd., New Delhi ( $4^{\text {th }}$ edition $)$

Ramesh, M.V.\&Lonsane, B.K. (1987), Solid state fermentation for production of $\alpha$-amylase by Bacillus megaterium 16M,Biotechnol. Lett, 9, 323-8

Ramesh, M.V.\&Lonsane B.K. (1988), Factors effecting recovery of thermostable $\alpha$-amylase from bacterial bran produced under SSF,Chem.Mikrobial Technol. Lebensm, 11, 155-9

Selvakumar, P, Pandey, A. (1999), Solid State fermentation for the synthesis of inulinase from Staphylo coccus sp and Kluyveromyces marxiams, Process Biochemistry, 34, 851-855. 
Stryer,L.(1975). Biochemistry, W.H Freeman and company NewYork; second Edition
Tunga, R, Banerjee, R, Bhattacharya, BC. (1999), Some studies on optimization of extraction process for protease for production in S.S.F, Bioprocess Engineering, 20, 485-489.
Received: April 16, 1999; Revised: January 07, 2000; Accepted: May 30, 2000. 